\title{
Uptake of sub-micrometre particles and dissolved organic material by Antarctic choanoflagellates
}

\author{
Harvey J. Marchant, Fiona J. Scott \\ Australian Antarctic Division, Channel Highway, Kingston, Tasmania, 7050 Australia
}

\begin{abstract}
Antarctic choanoflagellates ingest fluorescent latex microspheres over the size range 0.063 to $1.0 \mu \mathrm{m}$. They also ingest fluorescently labelled dextrans over the molecular weight range of $4 \times 10^{3}$ to $2 \times 10^{6}$ daltons. Calculations based on clearance rates and their abundance indicate that choanoflagellates in Antarctic coastal waters clear around $7 \%$ of the water column per day. They are likely to be involved in the direct transfer of energy from sub-micrometre particles and high molecular weight dissolved organic material to krill and other grazing invertebrates.
\end{abstract}

\section{INTRODUCTION}

Recent studies indicate that the concentration of dissolved organic carbon (DOC) in seawater is substantially higher than previously thought and that a substantial proportion of this material in surface waters has a molecular weight $>1 \times 10^{5}$ daltons (Sugimura \& Suzuki 1988, Toggweiler 1990). In addition, high concentrations $\left(10^{6}\right.$ to $10^{7}$ particles $\left.\mathrm{ml}^{-1}\right)$ of submicrometre particles $(0.4$ to $1.0 \mu \mathrm{m})$ and small colloids $(<0.12 \mu \mathrm{m})$ in seawater have been reported (Koike et al. 1990, Wells \& Goldberg 1991, Longhurst et al. 1992). These investigations highlight the problem of distinguishing between 'dissolved' (DOM) and 'particulate' (POM) organic material and the likely importance of sub-micrometre particles. The concentration of DOM with molecular weight $>6 \times 10^{4}$ daltons is higher than that of low molecular weight components in surface waters and decreases dramatically with depth in the upper few hundred metres (Sugimura \& Suzuki 1988). Koike et al. (1990) found a similar decline in the concentration of sub-micrometre particles with depth. Such a depth distribution however was not found by Wells \& Goldberg (1991) for colloids $<0.12 \mu \mathrm{m}$.

Choanoflagellates are a group of suspension-feeding protozoa that are ubiquitous in marine environments.
Their high numbers, particularly in inshore and polar waters $\left(10^{3}\right.$ to $10^{7}$ cells $\left.1^{-1}\right)$, indicate that they are likely to play a significant role in marine food webs (Marchant 1985, Buck \& Garrison 1988, Garrison \& Buck 1989, Buck et al. 1991). Choanoflagellates trap food particles on a ring of tentacles that surround a single flagellum. Their principal food is reportedly bacteria (Leadbeater \& Morton 1974, Fenchel 1982, Geider \& Leadbeater 1988) but they also consume picoplanktonic autotrophs (Laval 1971, Buck et al. 1991) and particulate organic material (Marchant 1985). Grazing rates have been reported for aloricate genera (Fenchel 1982, Cynar \& Sieburth 1986, Salonen \& Jokinen 1988) as well as the loricate species Diaphanoeca grandis (Andersen 1989, Marchant 1990) and Stephanoeca diplocostata (Geider \& Leadbeater 1988). Data on particle size selection and feeding rates are apparently lacking for these organisms that inhabit polar waters where they frequently occur in high abundance.

Choanoflagellates also take up high molecular weight DOM (Sherr 1988) and have been grown in axenic culture at high concentrations of DOM as their sole energy source (Gold et al. 1970). The heterotrophic uptake of DOM by protists has been the subject of considerable discussion (e.g. Haas \& Webb 1979, Porter et al. 1985, Fenchel 1987, Sherr 1988). The protistan utilization of DOC of differing molecular weight has 
received insufficient attention to ascertain the quantitative importance of this link in marine food webs.

In Antarctic coastal waters we have recorded high concentrations of DOM and POM coinciding with the bloom of the prymnesiophyte Phaeocystis. This seasonal peak occurs at the same time that choanoflagellates reach their seasonal maximum (Davidson \& Marchant 1992). In this paper we report the size of particles and molecular weight of DOM ingested by Antarctic choanoflagellates.

\section{MATERIAL AND METHODS}

Samples were taken from $5 \mathrm{~m}$ depth in the coastal area off the Australian Antarctic station of Davis $\left(68^{\circ} 34^{\prime} \mathrm{S}, 77^{\circ} 57^{\prime} \mathrm{E}\right)$ and from the surface of Organic Lake $\left(68^{\circ} 27^{\prime} \mathrm{S}, 78^{\circ} 12^{\prime} \mathrm{E}\right)$ in the Vestfold Hills at various times during the $1989 / 90$ and $1990 / 91$ dusiral summers. Organisms were concentrated by gentle filtration through $0.8 \mu \mathrm{m}$ pore size Nuclepore filters. Choanoflagellates concentrated in this way were incubated at $0^{\circ} \mathrm{C}$ in suspensions of fluorescent carboxylated latex microspheres (FM) (Polysciences) at concentrations in the order of $10^{5}$ to $10^{7} \mathrm{FM} \mathrm{ml}^{-1}$. FM were treated with $10 \mathrm{mg} \mathrm{ml}^{-1}$ bovine serum albumin (Sigma) before the incubations to prevent clumping (Pace \& Bailiff 1987). To ascertain the size of particles that the various species of choanoflagellates could ingest, cultures were incubated in FM ranging in diameter from 0.063 to $1.97 \mu \mathrm{m}$ for $1 \mathrm{~h}$. Whether or not FM were ingested was determined by examination of at least 100 cells of each species on 3 occasions using a Zeiss WL microscope fitted with transmitted phase contrast and incident fluorescence optics. Separate time-course incubations were made to measure the uptake rate of FM 0.25 and $0.50 \mu \mathrm{m}$ in diameter by Acanthocorbis unguiculata from Organic Lake. At various times aliquots were taken and the number of FM ingested by between 24 and 217 (mean 118) cells was counted by fluorescence microscopy. No attempt was made to control the ratio of cells to FM concentra- tions in these incubations. Cells containing FM were either counted directly without fixation or following treatment with $1 \%$ glutaraldehyde and without further concentration to overcome the problem of distinguishing whether FM have been ingested or attached to the cell surface (Cynar \& Sieburth 1986). No evidence of the fixative-induced egestion of the contents of food vacuoles as reported by Sieracki et al. (1987) was detected.

To determine whether these organisms took up dissolved organic material, they were incubated for $1 \mathrm{~h}$ at $0{ }^{\circ} \mathrm{C}$ in FITC-labelled dextrans (Sigma) of molecular weights ranging from $4 \times 10^{3}$ to $2 \times 10^{6}$ daltons at a concentration of $2 \mathrm{mg} \mathrm{l}^{-1}$. Whether the dextrans were ingested was determined from the fluorescence of the food vacuoles of not less than 100 individuals of the various species on 4 occasions.

\section{RESULTS}

The sizes of FM ingested by various species of Antarctic choanoflagellates are given in Table 1. Most species ingested FM over the size range 0.063 to $1.0 \mu \mathrm{m}$. None took up FM $>1.0 \mu \mathrm{m}$ and only Calliacantha natans was not seen to take up FM $\geq 1.0 \mu \mathrm{m}$ in diameter. The FM accumulated in food vacuoles located at the posterior end of the cell. After $30 \mathrm{~min}$ incubation in FM at the same concentration, about $25 \%$ of Acanthocorbis unguiculata cells had ingested FM of $1 \mu \mathrm{m}$ diameter but more than $80 \%$ of cells had taken up FM $0.25 \mu \mathrm{m}$ in diameter and close to $100 \%$ of these cells had ingested FM $0.5 \mu \mathrm{m}$ in diameter in the same time (Fig. 1). Despite the relatively low proportion of the choanoflagellate population taking up $1 \mu \mathrm{m}$ beads, high numbers of these beads had accumulated on the feeding tentacles. Maximum uptake rate of $A$. unguiculata when incubated with $0.5 \mu \mathrm{m}$ beads was around $27 \mathrm{FM} \mathrm{cell}^{-1} \mathrm{~h}^{-1}$ at a concentration of $3 \times 10^{7} \mathrm{FM} \mathrm{ml}^{-1}$ and around $25 \mathrm{FM} \mathrm{cell}^{-1}$ $\mathrm{h}^{-1}$ at a concentration of $1 \times 10^{7} \mathrm{FM} \mathrm{m}^{-1}$ with beads of $0.25 \mu \mathrm{m}$ diameter (Fig. 2). Clearance rates for the 0.5 and $0.25 \mu \mathrm{m}$ diameter beads, determined from the slope

Table 1. Sizes of FM ingested by different species of Antarctic choanoflagellates. "No data

\begin{tabular}{lcccccc}
\hline Species & \multicolumn{5}{c}{ FM diameter $(\mu \mathrm{m})$} \\
& 0.063 & 0.096 & 0.25 & 0.5 & 1.0 & 1.97 \\
\hline Acanthocorbis unguiculata & + & + & + & + & + \\
Bicosta spinifera & + & + & + & + & + \\
Calliacantha natans & + & + & + & + & + \\
Crinolina aperta & + & + & + & + & + \\
Diaphanoeca grandis & + & + & + & + & - \\
Monosiga sp. & + & + & + & + \\
Parvicorbicula socialis & + & + & + & + \\
Stephanoeca sp. & + & + & + \\
\hline
\end{tabular}


near the origin in Fig. 2, give values of around $3 \mathrm{nl}$ cell ${ }^{-1} \mathrm{~h}^{-1}$ and $1.3 \mathrm{nl} \mathrm{cell}^{-1} \mathrm{~h}^{-1}$ respectively.

Table 2 indicates the molecular weight of the FITC-labelled dextrans taken up by the different species of choanoflagellates after $1 \mathrm{~h}$ incubation. All species investigated took up dextrans with a molecular weight $>71000$ daltons but they differed in their ability to ingest dextrans of lower molecular weight. The lowest molecular weight dextran, 4000 daltons, was only detected in the food vacuoles of Acanthocorbis unguiculata and Diaphanoeca grandis. The percentage of cells in populations of these 2 organisms ingesting dextrans of different molecular weight after $1 \mathrm{~h}$ incubation is shown in Fig. 3. Apparently A. unguiculata is better able to take up dextrans with a molecular weight between 17000 and 150000 daltons than $D$. grandis but a higher percentage of $D$. grandis cells are able to assimilate dextrans with a molecular weight of 4000 daltons.

The fluorescence of the FITC-labelled dextrans could not be distinguished in the incubation solution nor could it be detected in the cytoplasm of the choanoflagellates, indicating that it was not being

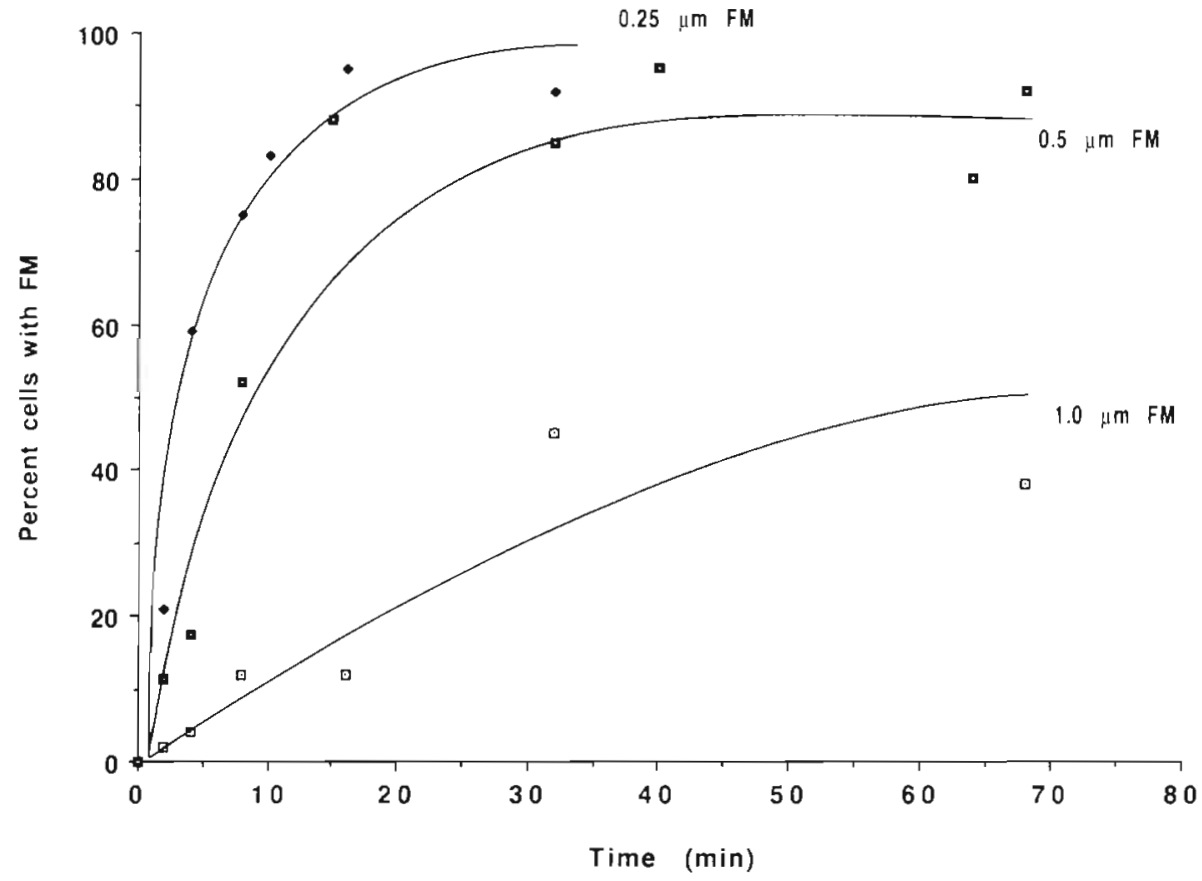

Fig. 1. Acanthocorbis unguiculata. Time course of the percentage of cells that had ingested FM of various diameters

concentrated anywhere other than the food vacuoles. Although bacteria were present in the incubations none were seen to be fluorescent, indicating that they had not assimilated the labelled dextran. The fluorescence in the food vacuoles appeared uniform, suggesting that the choanoflagellate had phagocytosed the FITC-labelled dextran directly rather than ingesting bacteria that had incorporated labelled dextran.
Fig. 2. Acanthocorbis unguiculata. Uptake rates of 0.25 and $0.5 \mu \mathrm{m}$ diameter $\mathrm{FM}$ as a function of FM concentration. Error bars indicate $95 \%$ confidence limits for each uptake rate measurement

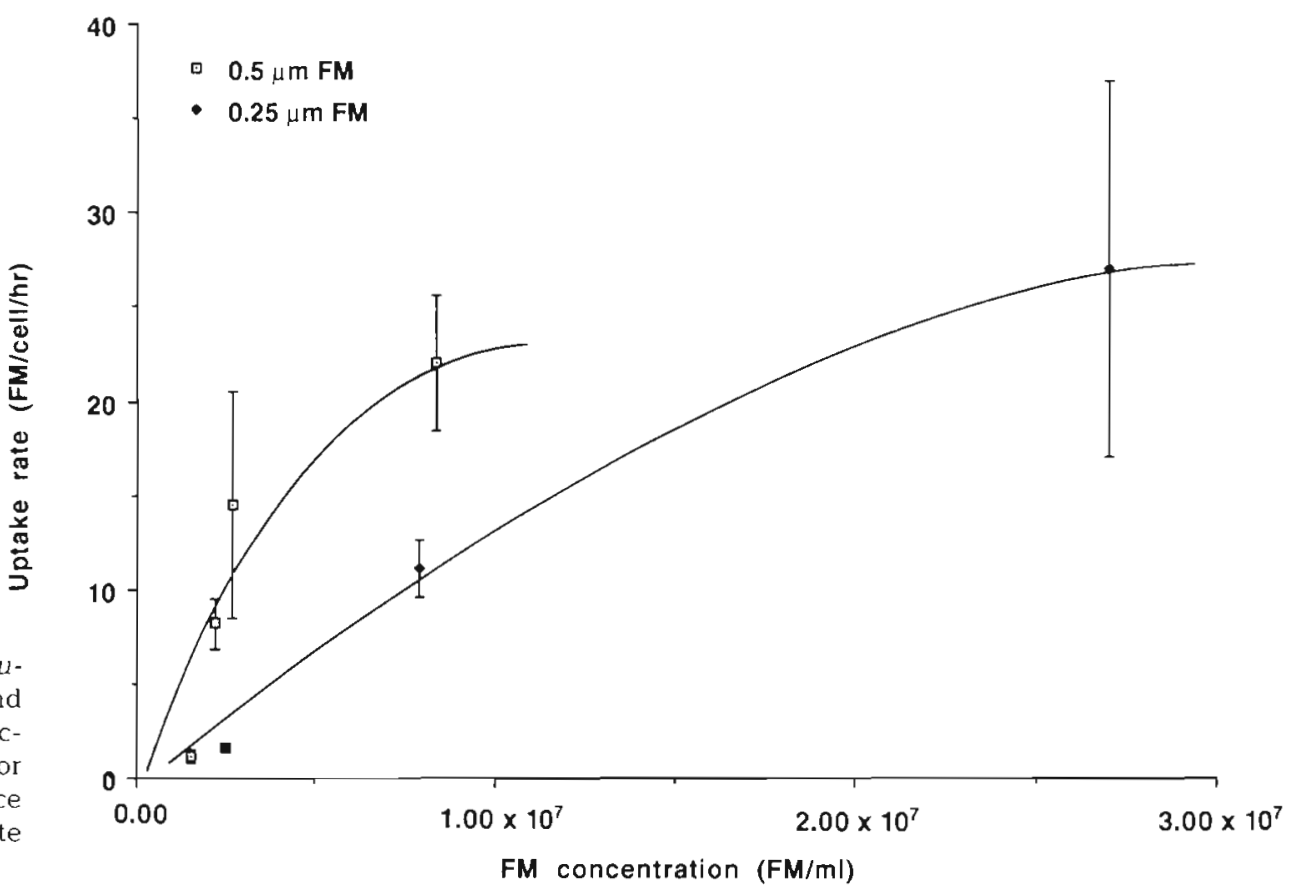


Table 2. Molecular weight of FITC-labelled dextrans taken up by different species of Antarctic choanoflagellates

\begin{tabular}{|c|c|c|c|c|c|c|c|c|}
\hline \multirow[t]{2}{*}{ Species } & \multicolumn{8}{|c|}{ FITC dextran MW (daltons) } \\
\hline & $3.9 \mathrm{~K}$ & $9.4 \mathrm{~K}$ & $17 \mathrm{~K}$ & $36 \mathrm{~K}$ & $71 \mathrm{~K}$ & $149 \mathrm{~K}$ & $506 \mathrm{~K}$ & $2000 \mathrm{~K}$ \\
\hline Acanthocorbis unguiculata & + & + & + & + & + & + & + & + \\
\hline Bicosta spinifera & - & - & + & + & + & + & + & + \\
\hline Calliacantha natans & - & + & + & + & + & + & + & + \\
\hline Crinolina aperta & - & - & - & + & + & + & + & + \\
\hline Diaphanoeca grandis & + & + & + & + & + & + & + & + \\
\hline Parvicorbicula socialis & - & - & - & - & + & + & + & + \\
\hline
\end{tabular}

\section{DISCUSSION}

Antarctic choanoflagellates are able to ingest microspheres as small as $0.063 \mu \mathrm{m}$ in diameter indicating that these suspension-feeding protozoa are able to ingest particles of colloidal size. Previous studles showed Mionosiga sp. ingests particles $0.21 \mu \mathrm{m}$ in diameter (Salonen \& Jokinen 1988) and Diaphanoeca grandis ingests microspheres at least as small as 0.25 $\mu \mathrm{m}$ in diameter (Marchant 1990), about the size of the smallest bacteria. As was found with $D$. grandis (Marchant 1990) a much higher proportion of cells within a population of Acanothocorbis ungiculata take up FM with a diameter of 0.25 and $0.5 \mu \mathrm{m}$ compared to $1 \mu \mathrm{m}$ diameter FM.

There has been a long-held view that choanoflagellates are an ecologically homogeneous group, the principal food of which is bacteria. Although there is no doubt that bacteria are a major component of their diet, it is now apparent that they ingest a variety of food items. Buck et al. (1991) reported that off the coast of California (USA) $17 \% \pm 18 \%$ of the choanoflagellates

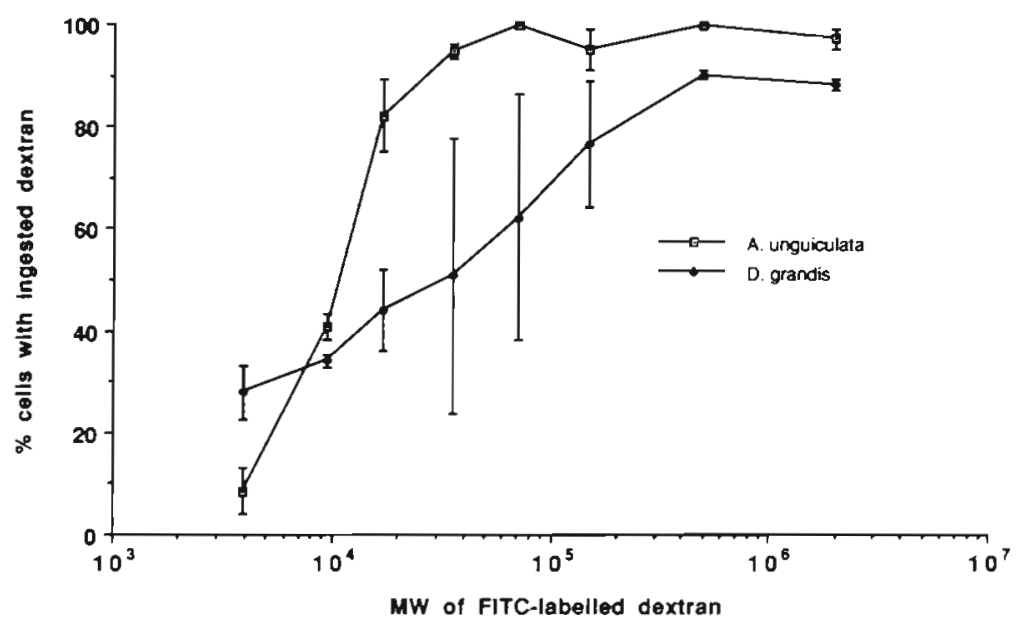

Fig. 3. Acanthocorbis unguiculata and Diaphanoeca grandis. Mean percentages of cells ingesting dextrans of different molecular weights. The bars signify the range of values obtained from counts of at least 100 cells from 4 incubations at each molecular weight had cyanobacteria or red fluorescing picoplankton in their food vacuoles. Finding that Diaphanoeca grandis and Acanthocorbis unguiculata took up FITC-labelled dextrans with a MW as low as 4000 daltons is evidence supporting the contention that choanoflagellates are an ecologically heterogeneous group, in which different species exploit different food sources (Marchant 1990). It is significant in this regard that both $D$. grandis and $A$. unguiculata, those choanoflagellates that fed over the widest size spectrum, persist throughout the year at an Antarctic coastal site while others occurred in either summer or winter only (Marchant \& Perrin 1990). In this paper we show that different species can feed over a size range spanning 4000 daltons $(<0.005 \mu \mathrm{m})$ to $1 \mu \mathrm{m}$ and that there is apparently some size selectivity between species. In Antarctic coastal waters, although some species are present throughout the year, there are others that are found only in winter while those that occur in high numbers in summer are absent during the winter (Marchant \& Perrin 1990). Other studies have shown differences in the abundance of choanoflagellates in the Weddell Sea and suggest that different species may be responding differently to resources (Buck \& Garrison 1988).

The extent to which DOM is a component of the diet of protozod is equivocal. While there is little doubt that these organisms are able to ingest DOM at high concentration, evidence for them doing so when the DOM is present at concentrations found in nature is less compelling. This argument is clouded by the fact that DOM comprises an extremely wide range of compounds with molecular weights ranging from around 100, in the case of monosaccharides and amino acids, to millions, in the case of colloids and submicrometre particles that pass through filters that are used to segregate the 'dissolved' from the 'particulate' fractions. Protozoa will be out-competed by bacteria for low molecular weight compounds as 
Table 3. Maximum clearance rates of choanoflagellates at different temperatures

\begin{tabular}{|lccl|}
\hline Organism & $\begin{array}{c}\text { Clearance rate } \\
\left(\mathrm{nl} \mathrm{cell}{ }^{-1} \mathrm{~h}^{-1}\right)\end{array}$ & $\begin{array}{c}\text { Temp. } \\
\left({ }^{\circ} \mathrm{C}\right)\end{array}$ & Source \\
\hline Diaphanoeca grandis & 16 & 15 & Andersen (1989) \\
D. grandis & 0.7 & 0 & Marchant $(1990)$ \\
Acanthocorbis unguiculata & 3 & 0 & This study \\
Stephanoeca diplocostata & 3 & 18 & Geider \& Leadbeater (1988) \\
Monosiga sp. & 2 & 20 & Fenchel (1982) \\
Monosiga sp. & 2.5 & $15-23$ & Salonen \& Jokinen (1988) \\
Codosiga sp. & 0.4 & 20 & Cynar \& Sieburth (1986) \\
\hline
\end{tabular}

uptake by diffusion is inversely proportional to length ${ }^{2}$ of an organism (Fenchel 1987). Numerous studies have shown that bacteria preferentially and more rapidly utilize low molecular weight DOC than high molecular weight material (e.g. Ogura 1977, Jensen 1983, Lancelot 1984, Sherr 1988). Bacteria must first exoenzymatically hydrolyze high molecular weight compounds before they are assimilated.

Sherr (1988) found that the aloricate choanoflagellate Codosiga sp. ingested FITC-labelled dextrans with a molecular weight $\geq 5 \times 10^{5}$ daltons at a concen-

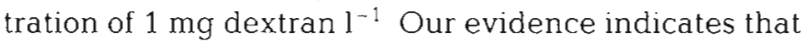
some loricate choanoflagellates are able to ingest FITC-labelled dextrans with molecular weights as low as 4000 daltons at a concentration of $2 \mathrm{mg} \mathrm{l}^{-1}$ which is equivalent to $0.8 \mathrm{mg}$ carbon $\mathrm{1}^{-1}$. The concentration of DOC in open Antarctic waters varies little (Billen et al. 1987) but in coastal waters and associated with blooms of Phaeocystis it has been found to vary widely (Bölter \& Dawson 1982, Davidson \& Marchant 1992). High molecular weight material often makes up a considerable fraction of total dissolved organic carbon in natural waters (Wheeler 1976, Ogura 1977. Sugimura \& Suzuki 1988). Therefore, choanoflagellates may shortcircuit the microbial loop of the food web by utilising detrital carbon that would otherwise be transported away or broken down and assimilated by bacteria before they are grazed by protozoa, including choanoflagellates themselves.

Although data have been reported on the size spectrum of DOM in marine environments there are none to our knowledge from Antarctic waters. In temperate and tropical oceans its total concentration is highly variable and substances with a molecular weight $>1.0$ $\times 10^{5}$ constitute a significant component of it in nearsurface waters (Wheeler 1976, Ogura 1977, Sugimura \& Suzuki 1988). However, such high molecular weight DOM is not present below the upper few hundred metres (Sugimura \& Suzuki 1988).

Clearance rates have been published for only a few species of choanoflagellates (Table 3). Of these few determinations, interspecific variation and differences attributable to temperature are clear. In addition, as demonstrated in this paper and shown for other protozoa (Fenchel 1986), clearance is a function of particle size. At a clearance rate of $3 \mathrm{nl} \mathrm{cell}^{-1} \mathrm{~h}^{-1}$ and a concentration of $1 \times 10^{6}$ cells $1^{-1}$, indicative values for Antarctic waters, choanoflagellates would clear around $7 \%$ of the surface waters per day. In comparison, Andersen (1989) calculated that choanoflagellates in Danish coastal waters would clear around $25 \%$ of the water column per day and that between $<0.1$ and $180 \%$ (mean $6 \%$ ) of the water column was cleared per day by choanoflagellates off central California (Buck et al. 1991). The difference between the proportions of Antarctic and Danish water cleared is due principally to the differences in clearance rates (Table 3).

Filter-feeding planktonic tunicates have been shown to remove colloidal sized particles $>0.2 \mu \mathrm{m}$ by Flood et al. (1992) who proposed that these organisms are likely to mediate a substantial energy flow from DOC to their predators, fish, thus by-passing the respirational losses of bacterial and protozoan links in the food web. They also speculated that other filter feeders share the ability to utilize colloidal DOC. Our investigations indicate that choanoflagellates are also likely to be removing and repackaging not only colloidal DOC but smaller molecules as well. There are few data on the quantitative importance of this utilization of high molecular weight DOC by filter feeders.

Choanoflagellates are a conspicuous component in the diet of Euphausia superba (Marchant \& Nash 1986, Tanoue \& Hara 1986). Tanoue \& Hara (1986) reported that choanoflagellate cytoplasm, predominantly Parvicorbicula socialis, accounts for approximately $10 \%$ of the volume of the euphausiid faecal material and suggested that choanoflagellates may function as a direct link between picoplankton as well as both DOM and POM to metazoan grazers. Our demonstration here of the uptake of colloid-sized particles and DOM over a wide span of molecular weights provides strong evidence in support of this hypothesis. 
Acknowledgements. We thank J. Laybourn-Parry and B Leadbeater for discussions and S. Nicol and P. Quilty for comments on the manuscript.

\section{LITERATURE CITED}

Andersen, P. (1989). Functional biology of the choanoflagellate Diaphanoeca grandis Ellis. Mar. microb. Food Webs 3 : $35-50$

Billen, G., Lancelot, C. Mathot, S. (1987). Programme de recherches scientifiques sur l'Antarctique; biochemie de la criossance du phyto-et du bacterioplancton. Research Report, Université Libre de Bruxelles

Bölter, M., Dawson, R. (1982). Heterotrophic utilisation of biochemical compounds in Antarctic waters. Neth. J. Sea Res. 16: $315-332$

Buck, K. R., Chavez, F. P., Thomsen H. A. (1991) Choanoflagellates of the central California waters: abundance and distribution. Ophelia 33: 179-186

Buck, K. R., Garrison, D. L. (1988). Distribution and abundance of choanoflagellates (Acanthoecidae) across the ice edge zone in the Weddell Sea. Mar. Biol. 98: 263-269

Cynar, F. J., Sieburth, J. McN. (1986). Unambiguous detection and improved quantification of phagotrophy in apochlorotic nanoflagellates using fluorescent microspheres and concomitant phase contrast and epifluorescence microscopy. Mar. Ecol. Prog. Ser. 32:61-70

Davidson, A. T., Marchant, H. J. (1992). Protist interactions and carbon dynamics of a Phaeocystis-dominated bloom at an Antarctic coastal site. Polar Biol. 2: 387-395

Fenchel, T (1982). Ecology of heterotrophic microflagellates. II. Bioenergetics and growth. Mar. Ecol. Prog. Ser. 8: $225-231$

Fenchel, T. (1986). Protozoan filter feeding. Prog. Protistol. 1: $65-113$

Fenchel, $T$ (1987). Ecology of protozod. Science Tech, Inc., Madison

Flood, P. R., Deibel, D., Morris, C. C. (1992). Filtration of colloidal melanin from seawater by planktonic tunicates. Nature 355: 630-632

Garrison, D. L., Buck, K. R. (1989). Protozooplankton in the Weddell Sea, Antarctica: abundance and distribution in the ice-edge zone. Polar Biol. 9: 341-351

Geider, R. J., Leadbeater, B. S. C. (1988). Kinetics and growth of the marine choanoflagellate Stephanoeca diplocostata. Mar. Ecol. Prog. Ser. 47: 169-177

Gold, K., Pfister, R. M., Liguori, V. R. (1970). Axenic cultivation of two species of Choanoflagellida. J. Protozool. 17: $210-212$

Haas, L. W., Webb, K. L. (1979). Nutritional mode of several non-pigmented microflagellates from the York River estuary, Virginia. J. exp. mar. Biol Ecol. 39: 125-134

Jensen, L. M. (1983). Phytoplankton release of extracellular organic carbon, molecular weight composition, and bacterial assimilation. Mar. Ecol. Prog. Ser. 11. 39-48

Koike, I., Hara, T., Teraguchi, T., Kogure, K. (1990). Role of sub-micrometre particles in the ocean. Nature 345 : $242-244$

Lancelot, C. (1984). Extracellular release of small and large molecules by phytoplankton in the southern bight of the North Sea. Estuar. coast. Shelf Sci. 18: 65-77

Laval, M. (1971). Ultrastructure et mode de nutrition du choanoflagelle Salpingoeca pelagica sp. nov. Comparaison avec les choanocytes des spongaires. Protistologica 7: 325-336

Leadbeater, B. S. C., Morton, C. (1974). A microscopical study of a marine species of Codosiga James-Clark (Choanoflagellata) with special reference to the ingestion of bacteria. Biol. J. Linn. Soc. 6:337-347

Longhurst, A. R., Koike, I., Li, W. K. W., Rodriguez, J., Dickie, P., Kepay, P., Partensky, F., Bautista, B., Ruiz, J., Wells, M., Bird, D. F. (1992). Sub-micron particles in northwest Atlantic shelf water. Deep Sea Res. 39: 1-7

Marchant, H. J. (1985). Choanoflagellates in the Antarctic marine food chain. In: Siegfried, W. R., Condy, P. R., Laws, R. M. (eds.) Antarctic nutrient cycles and food webs. Springer-Verlag, Berlin, p. 271-276

Marchant, H. J. (1990). Grazing rate and particle size selection by the choanoflagellate Diaphanoeca grandis from the sea-ice of Lake Saroma, Hokkaido. Proc. NIPR Symp. Polar Biol. 3: 1-7

Marchant, H. J., Nash, G. V. (1986) Electron microscopy of gut contents and faeces of Euphausia superba Dana. Mem. natn. Inst. Polar Res., Spec. Issue 40: 167-177

Marchant, H. J., Perrin, R. (1990). Seasonal variation in abundance and species composition of planktonic choanoflagellates (Acanthoeridae) at an Antarctic coastal site. Polar Biol. 10: 499-505

Ogura, N. (1977). High molecular weight organic matter in seawater. Mar. Chem. 5: 535-549

Pace, M. L., Bailiff, M. D. (1987). Evaluation of a fluorescent microsphere technique for measuring grazing rates of phagotrophic microorganisms. Mar. Ecol. Prog. Ser. 40: $185-193$

Porter, K. G., Sherr, E. B., Sherr, B. F., Pace, M., Sanders, R. W. (1985). Protozoa in planktonic food webs. J. Protozool. 32 : 409-415

Salonen, K., Jokinen, S. (1988). Flagellate grazing on bacteria in a small dystrophic lake. Hydrobiologia 161: 203-209

Sherr, E. (1988). Direct use of high molecular weight polysaccharide by heterotrophic flagellates. Nature 335: 348-351

Sieracki, M. E., Hass, L. W., Caron, D. A., Lessard, E. J. (1987). Effect of fixation on particle retention by microflagellates: underestimation of grazing rates. Mar. Ecol. Prog. Ser. 38: $251-258$

Sugimura, Y., Suzuki, Y. (1988). A high-temperature catalytic oxidation method for the determination of non-volatile dissolved organic carbon in seawater by direct injection of a liquid sample. Mar. Chem. 24: 105-131

Tanoue, E., Hara, S. (1986). Ecological implications of faecal pellets produced by the Antarctic krill Euphausia superba in the Antarctic Ocean. Mar. Biol. 91: 359-369

Toggweiler, J. R. (1990). Diving into the organic soup. Nature 345: 203-204

Wells, M. L., Goldberg, E. D. (1991). Occurrence of small colloids in seawater. Nature 353: 342-344

Wheeler, J. R. (1976). Fractionation by molecular weight of organic substances in Georgia coastal water. Limnol. Oceanogr. 21.846-852

Manuscript first received: July 28, 1992

Revised version accepted: November 16, 1992 